\title{
Sea surface microlayer and bacterioneuston spreading dynamics
}

\author{
Michelle S. Hale*, James G. Mitchell \\ School of Biological Sciences, Flinders University of South Australia, PO Box 2100, Adelaide, South Austrialia 5001, Australia
}

\begin{abstract}
The sea surface microlayer (SSM) has been well studied with regard to its chemical and biological composition, as well as its productivity. The origin and dynamics of these natural communities have been less well studied, despite extensive work on the relevant physical parameters, wind, turbulence and surface tension. To examine the effect these processes have on neuston transport, measurements of wind-driven surface drift, surfactant spreading and bacterial transport in the SSM were made in the laboratory and in the field. Spreading rates due to surface tension were up to approximately $17 \mathrm{~km} \mathrm{~d}^{-1}\left(19.7 \mathrm{~cm} \mathrm{~s}^{-1}\right)$ and were not significantly affected by waves. Wind-induced surface drift was measured in the laboratory. Wind speeds of 2 to $5 \mathrm{~m} \mathrm{~s}^{-1}$ produced drift speeds of 8 to $14 \mathrm{~cm} \mathrm{~s}^{-1}$, respectively. We demonstrate that bacteria spread with advancing slicks, but are not distributed evenly. Localised concentrations were found at the source and the leading edge of spreading slicks The Reynolds ridge, a slight rise in surface level at the leading edge of a spreading slick, may provide a mechanism by which bacteria are concentrated and transported at the leading edge. Bacteria already present at the surface were not pushed back by the leading edge, but incorporated and spread evenly across the slick. The spreading process did not result in the displacement of extant bacterioneuston communities. The results indicate surface tension and wind-induced surface drift may alter distributions and introduce new populations into neustonic communities, including communities distant from the point source of release.
\end{abstract}

KEY WORDS: Sea surface microlayer - Bacterioneuston - Surface transport

\section{INTRODUCTION}

Surface microlayers exist naturally in both marine and freshwater environments and are a common and widespread phenomenon. They can often be seen on coastal waters and lakes as slicks or calm streaks on a rippled surface, when the wind is light. Compression of film material through wind action and internal waves (Ewing 1950) results in an enrichment in organic material at the air-water interface. The surface active properties of these slick-forming compounds lower the surface tension at the interface, causing a damping effect on capillary waves (Romano \& Marquet 1991), and give the surface a smooth, glassy appearance. However, natural surface films can be found on all waters whether a visible slick is present or not (Duce et al. 1972).

Studies examining the sea surface microlayer (SSM) have focused primarily on the chemical and biological

·E-mail: michelle.hale@flinders.edu.au composition (Carlson 1982, Hardy et al. 1985, Maki 1993), while microlayer transport and its influence on the spatial and temporal dynamics of neuston communities has received little attention.

In surface layer spreading, transport is a 2-dimensional process controlled by 2 separate processes, surfactant composition and wind speeds. Surfactants possess a characteristic chemical structure consisting of a hydrophobic and a hydrophilic part. Spreading is caused by lowering surface tension and modification of interfacial interactions (Myers 1992). When a surfactant is added to the surface of water, spreading is initially rapid and decreases in velocity as the surface tension decreases. This continues until the supply of surfactant from the source is depleted and a monomolecular slick is formed (Aveyard et al. 1993).

Previous laboratory studies have examined spreading in terms of relative changes in surface tension, using surface tensiometers (Adamson 1990, Myers 1992). However, this does not provide a direct mea- 
surement of the spreading rate, although it can be used to predict whether spreading will occur. Furthermore, surface tension at the air-water interface decreases during the spreading process, making it difficult to predict spreading rates, hence they are routinely determined by direct observation of spreading events (Aveyard et al. 1993).

The spreading process is confined to the region immediately adjacent to the perimeter of the spreading substance (Adamson 1990). Consequently, if talcum powder or some other inert powder is sprinkled on the water surface and a drop of surfactant is added, the spreading liquid sweeps the talcum powder back as an accumulating ridge at the periphery of the film, but the talcum powder further away is undisturbed.

Whilst data and models exist for the dispersion of particulate matter (including pollutants) and dispersion of oil from spills (Al-Rabeh et al. 1992, Al-Rabeh \& Gunay 1992), these rates are determined exclusively by meteorological conditions, as particulate matter and oil slicks do not actively spread along surface tension gradients (Adamson 1990).

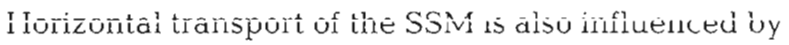
wind-driven surface currents. Studies of wind and the effects on surface waters have dealt mainly with the characteristic accumulation of slicks by Langmuir circulation (Wright \& Keller 1971, Lange \& Hühnerfuss 1978, Weller \& Price 1988) with little emphasis placed on the importance of the net horizontal transport induced by wind acting on the surface. Such studies have focused primarily on the physical processes occurring, with little emphasis on the importance of these processes to neuston distributions.

As the microlayer contains high concentrations of bacterioneuston compared to underlying bulk waters (Kjelleberg et al. 1979, Plusquellec et al. 1991), horizontal transport in SSMs may be of particular importance as a mechanism permitting bacteria to cross water mass boundaries (Hardy et al. 1985). If SSM transport acts independent of bulk water circulation, it may be difficult to accurately predict the fate of bacterioneuston from bulk circulation patterns. Rates of surfactant spreading in the field (for biologically relevant compounds), and the extent to which the chemistry and biology of surface waters may be altered, are unknown.

This study examines the influence of wind-induced surface drift and active surfactant spreading on SSM transport and horizontal distributions of bacterioneuston. This is of interest because wind-driven transport of the microlayer, coupled with active spreading of surfactants along surface tension gradients, may provide a unique and rapid mechanism of dispersal across hundreds to thousands of kilometres across the open ocean (Hale \& Mitchell 1995). Surfactants introduced to the marine environment from terrestrial sources may be capable of dispersing bacteria large distances along surface tension gradients, leading to alteration of neustonic and planktonic communities distant from the source

To examine the relative contributions of windinduced surface drift and surface tension gradients to horizontal transport, we developed small scale techniques for measuring spreading rates and surface drift. After establishing that our method for spreading measurement compared favourably with previous studies, we examined the potential of the system to study bacterial transport

\section{MATERIALS AND METHODS}

Surfactant spreading rates. Spreading rates were measured tor vegetable oil, motor oil, selective culture media, bile (30 $\mathrm{g} \mathrm{l}^{-1}$ ) (OXOID, Basingstoke, England), and froth from treated sewage. Previous studies have examined the spreading rates of alkanes and alcohols (Dev ei di. 1964 , Kaii \& Sansare 19700 , O'Brien ei al 1976), however, these surfactants are unsuitable for culturing bacteria. For this reason, compounds were chosen based on their ability to support bacterial growth or the likelihood of being found as components of terrestrial runoff. Bile contains bile salts that have strongly hydrophobic and hydrophilic parts characteristic of surfactants (Schmidt-Nielson 1990). Bile salts play an important role in the emulsification of dietary fats and are excreted in faeces, making them a major component of sewage effluent (Haslewood 1967).

Experiments were conducted in the laboratory at $18.5^{\circ} \mathrm{C}$. A $70 \times 250 \mathrm{~cm}$ tank was thoroughly cleaned and rinsed 3 times with tap water and twice with distilled water to remove any residual surfactants. A video camera was placed directly over the tank, to record spreading events. The tank was filled with filtered seawater to a depth of $10 \mathrm{~cm}$ and talcum powder was sprinkled lightly across the surface of the water to aid in discerning the slick (Davies \& Rideal 1963, Lange \& Hünnerfuss 1978). The water was left for 5 min to allow turbulence to dissipate, until no remnant surface currents were observed in the talc.

Volumes of slick material between $250 \mu \mathrm{l}$ and $10 \mathrm{ml}$ were added directly to the surface of the water at one end of the tank. Four replicate slicks were made for each volume and the tank was drained and washed between replicates. Each spreading event was recorded using the video camera and experiments were analysed using frame-by-frame video analysis (Mitchell et al. 1995).

To determine if spreading rates measured in the laboratory could be applied to open water, spreading 
experiments were also conducted in the field, in shallow waters beyond the surf zone. The water in the vicinity of the slick source was sprinkled lightly with talcum powder and $10 \mathrm{ml}$ of bile was added to the surface. Bile was chosen for use in the field experiments for 3 reasons: firstly, because it exhibited the fastest spreading rate of the substances trialed, thus making it sensitive to edge effects; secondly, because bile slick spreading showed little variation; and thirdly, because bile is associated with faecal matter and is a component of sewage effluent (Haslewood 1967). The leading edge of the slick was timed across $5 \mathrm{~m}$, at $1 \mathrm{~m}$ intervals.

Simultaneously, a hand-held anemometer (Deuta Anemowerke, Bergisch, Germanyl was used to measure wind speed at $1 \mathrm{~m}$ above the water surface. Water temperature was recorded and wave height was estimated by direct observation. Trials were run on 2 separate days and 4 replicate slicks were run on each day.

Surface drift. To determine rates of surface drift at different wind speeds, experiments were conducted in the laboratory in the tank described previously. A 3 speed fan was set up at one end of the tank. Wind speed was measured along the length of the tank to ensure that it remained constant. The video camera was mounted directly over the tank, as in the previous experiments.

In a closed tank or channel where steady state conditions exist, the net mass flux across any vertical transverse cross section of the tank must be zero. Therefore, if there is wind-driven transport of the surface microlayer in one direction, there is a subsequent build up of a subsurface return current. The return current has been shown to build up in approximately $L / u$ seconds, where $L$ is the length of the tank and $u$ is the drift velocity (Lange $\&$ Hünnerfuss 1978). The subsurface return current builds up once the surface current has reached the opposite end of the tank. To avoid taking measurements when any subsurface currents were established, trials were run in order to estimate the time taken for the subsurface return current to develop for each wind speed. All further measurements of surface drift were taken within this time.

Talcum powder was sprinkled lightly across the surface and the wind-driven transport of the talc across the surface was videotaped. Trials were run at wind speeds of 2, 3 and $5 \mathrm{~m} \mathrm{~s}^{-1}$. Talcum powder was used in preference to floats because measurement of windinduced drift depends significantly on the depth of float submergence (Wright \& Keller 1971) and talcum powder does not extend beyond the microlayer (Lange \& Hühnerfuss 1978). Videotaped experiments were analysed as described previously.

To determine the effect of surface drift on surfactant spreading, the surface drift experiments described above were repeated, with the addition of $1 \mathrm{ml}$ bile to the side of the tank

Bacterial distributions. Bacterial distributions were determined for inoculated bile slicks. Sterile bile $(30 \mathrm{~g}$ $\left.\mathrm{1}^{-1}\right)$ samples were inoculated with Vibrio natriegens and incubated for $2.5 \mathrm{~h}$ in a shaking water bath at $28^{\circ} \mathrm{C}$. Samples were removed and left to equilibrate to room temperature $\left(18.5^{\circ} \mathrm{C}\right)$, prior to experiments. Experiments were run in a pre-sterilised glass, $20 \times$ $40 \mathrm{~cm}$ tank, filled with $2 \mathrm{l}$ of filtered, autoclaved sea water $\left(121^{\circ} \mathrm{C}\right.$ for $\left.15 \mathrm{~min}\right)$ and talcum powder was lightly sprinkled across the surface. Control samples for bacterial growth were taken for the inoculations and controls for contamination were taken for the water and talcum powder, by spreading $50 \mu$ of sample onto Vibrio Artificial Seawater (VAS) plates.

Samples were spread by adding $1 \mathrm{ml}$ of inoculated bile to the surface at the side of the tanks. Immediately following spreading, replicate $50 \mu$ samples were taken from the surface, at 6 positions along the tank: at the point source of slick release, in front of the leading edge, at the leading edge, and 5, 10, and $20 \mathrm{~cm}$ back from the leading edge. The samples were spread on VAS plates and sealed with Parafilm.

Bile inoculated with Vibrio natriegens was also spread over seawater inoculated with a red colony forming bacteria. Sterile copier paper disks were used to sample at the leading edge of the slick with millimeter resolution. All samples were incubated at $28^{\circ} \mathrm{C}$ for $24 \mathrm{~h}$ and the number of colony forming units (CFU) were counted. To ensure that individual distinct colonies formed, the inoculation concentration for the millimeter resolution experiments was 4 times lower than for the centimeter measurements. For each experiment, replicate slicks were made simultaneously, each in a separate tank

\section{RESULTS}

\section{Surfactant spreading rates}

Vegetable and motor oils did not actively spread, but remained as compact lenses. Bile and froth from sewage exhibited spontaneous spreading upon contact with the water surface. Spreading rates were initially very fast, but then rapidly decreased to a constant rate. Spreading rates were logarithmically transformed and a 2-way analysis of variance was applied to each set of data compared. There was no significant difference found in the spreading rates of 0.25 and $10 \mathrm{ml}$ of bile added to the side of the tank (Fig. 1). The average initial spreading rate was $19.7 \pm 1.1 \mathrm{~cm} \mathrm{~s}^{-1}$ ( \pm SD), which decreased exponentially to a constant rate of $8.4 \pm$ $1.2 \mathrm{~cm} \mathrm{~s}^{-1}$. Similarly the spreading rate of sewage froth 


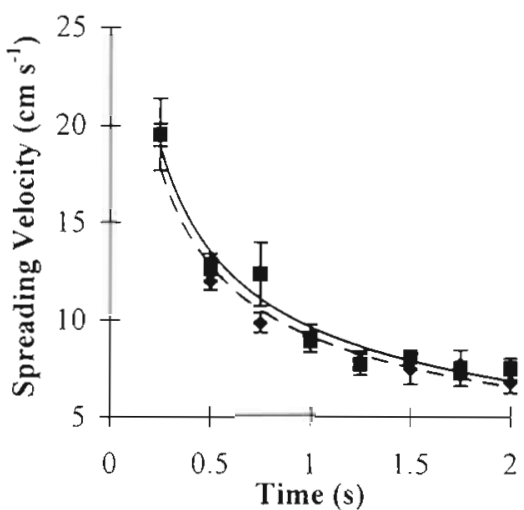

Fig. 1. Average spreading velocities of 0.25 ) and $10 \mathrm{ml}($ of bile spread in a $70 \times 200 \mathrm{~cm}$ tank. Lines represent the calculated least squares regressions of $0.25\left(---; R^{2}=0.89\right)$ and $10 \mathrm{ml}\left(-; R^{2}=0.88\right)$. Error bars are $95 \%$ confidence intervals

was initially $8.5 \pm 0.4 \mathrm{~cm} \mathrm{~s}^{-1}$, which decreased to a constant rate of $2.6 \pm 0.6 \mathrm{~cm} \mathrm{~s}^{-1}$.

Water temperature on both mornings in the field was $17.5^{\circ} \mathrm{C}$. Oñ both mornings, the wind did not register a reading on the hand-held anemometer and thus wind speeds were assumed to be close to zero $\left( \pm 0.2 \mathrm{~m} \mathrm{~s}^{-1}\right)$. No waves were present on the first morning and the surface of the water was smooth and glassy in appearance. On the second morning, waves with wave height of $20 \pm$ $1 \mathrm{~cm}$ and period of approximately $7 \pm 1 \mathrm{~s}$ were observed.

There was no significant difference in the change of spreading rates with time on the 2 mornings. Spreading rates of bile decreased significantly over the distance measured, with an initial spreading rate of $16.0 \pm$ $2.4 \mathrm{~cm} \mathrm{~s}^{-1}$ over the first $1 \mathrm{~m}$, decreasing to a rate of $5.3 \pm$ $1.1 \mathrm{~cm} \mathrm{~s}^{-1}$ after travelling $5 \mathrm{~m}$ (Fig. 2).

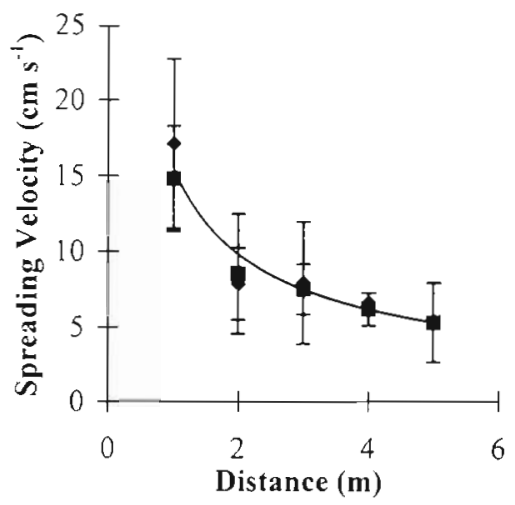

Fig. 2. Average spreading velocities of $10 \mathrm{ml}$ bile spread in the field on 2 days, one with ( $)$ and one without $(\bullet)$ waves. Line represents the calculated least squares regression $\left(R^{2}=0.91\right)$. Error bars are $95 \%$ confidence intervals

\section{Surface drift}

Estimations of surface drift were used to calculate the time required for the return subsurface current to develop. This was done in order to avoid measurements being taken during the flow of a subsurface current, to more accurately simulate open ocean conditions where such currents would be minimal in comparison with the strong return currents that are set up in closed systems such as tanks, ponds and lakes (Romano \& Marquet 1991). The results of the initial trials indicated wind speeds of 2,3 , and $5 \mathrm{~m} \mathrm{~s}^{-1}$ resulted in surface drifts of approximately 8,11 , and $15 \mathrm{~cm} \mathrm{~s}^{-1}$, respectively. Therefore, measurements had to be taken within approximately 25,19 , and $13 \mathrm{~s}$ for wind speeds of 2,3 , and $5 \mathrm{~m} \mathrm{~s}^{-1}$, respectively. All further measurements of surface drift where taken within these times.

Table 1. Comparison of various laboratory studies investigating the relationship between wind-induced surface drift speed (DS) and wind speed (WS) (adapted from Lange \& Hühnerfuss 1978)

\begin{tabular}{|c|c|c|c|c|c|c|}
\hline $\begin{array}{c}\text { Tank } \\
\text { length }(\mathrm{m})\end{array}$ & $\begin{array}{l}\text { Air duct } \\
\text { height (m) }\end{array}$ & $\begin{array}{c}\text { Water } \\
\text { depth }(\mathrm{m})\end{array}$ & $\begin{array}{l}\text { Method of drift } \\
\text { determination }\end{array}$ & $\begin{array}{l}\text { Wind speed } \\
\text { range }\left(\mathrm{m} \mathrm{s}^{-1}\right)\end{array}$ & $\begin{array}{l}\text { DS/WS } \\
(\times 100)\end{array}$ & Source \\
\hline 18 & 1 & 0.5 & Monolayer-oleyl álcohol & $2.4-8.5$ & $3.0-4.8$ & Lange \& Hühnerfuss (1978) \\
\hline 4.9 & Open & 0.28 & $\begin{array}{l}\text { Polyethylene spheres }\left(0.64 \mathrm{~cm}^{2}\right) \\
\text { and disks }(0.32-1.27 \mathrm{~cm} \text { diam })\end{array}$ & $2.2-7.9$ & $3.8-4.5$ & Wright \& Keller (1971) \\
\hline 14 & 0.3 & 1.2 & $\begin{array}{c}\text { Spheres }(0.08-1.0 \mathrm{~cm}) \text { and } \\
\text { disks }(0.25 \mathrm{~cm} \text { diam.) }\end{array}$ & $3.5-13.4$ & $2.8-4.8$ & Wu (1968) \\
\hline 13.7 & 0.61 & 0.11 & Wax paper disks $(0.6 \mathrm{~cm}$ diam.) & $3.6-12.8$ & 3.2 & Plate et al. (1969) \\
\hline 13.4 & 0.45 & 0.35 & Paper disks (0.6 cm diam.) & $2.5-10.0$ & $3.0-3.4$ & Mizuno \& Mitsuyasu (1973) \\
\hline 25 & Unknown & 0.8 & $\begin{array}{l}\text { Polystyrene spheres } \\
(0.04-0.3 \mathrm{~cm} \text { diam. })\end{array}$ & $7.0-12.0$ & $2.6-3.1$ & $\begin{array}{l}\text { Dobroklonskiy \& } \\
\text { Lesnikov (1972) }\end{array}$ \\
\hline 20 & 0.15 & 0.14 & Paraffin flakes & $3.0-12.0$ & 3.3 & Keulegan (1951) \\
\hline 3.7 & 0.61 & 0.1 & Crude oil, fuel slicks & $5.0-10.0$ & $2.8-3.2$ & O'Brien (1971) \\
\hline 45.7 & 1.02 & 0.92 & Paper disks $(0.6 \mathrm{~cm}$ diam.) & $3.1-9.1$ & $2.6-2.9$ & Shemdin (1972) \\
\hline 2.5 & 0.2 & 0.1 & Talcum powder & $2.0-5.0$ & 3.6 & Present study \\
\hline
\end{tabular}




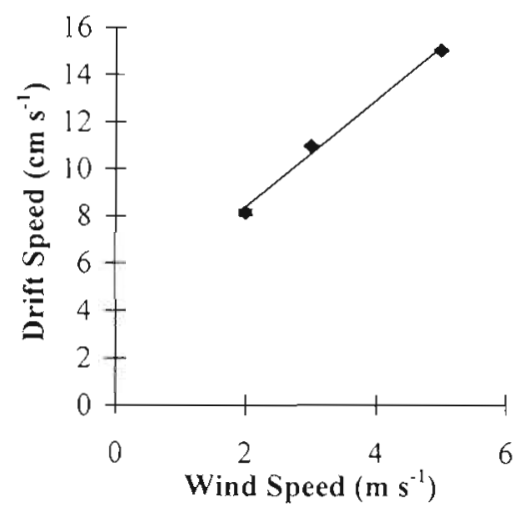

Fig. 3. Relationship between wind speed $\left( \pm 0.2 \mathrm{~m} \mathrm{~s}^{-1}\right)$ and wind-induced surface drift. Solid line represents the calculated least squares regression of drift speed (DS) versus wind speed (WS) $\left(R^{2}=0.99\right)$. Equation of line, $D S=3.9+2.3 W S$ (for

$2 \leq W S \leq 5 \mathrm{~cm}$ ). Error bars are $95 \%$ confidence intervals

The results of the surface drift experiments found that wind speeds of 2,3 , and $5 \mathrm{~m} \mathrm{~s}^{-1}$ resulted in surface drifts of $8.2 \pm 0.14,11.0 \pm 0.04$, and $15.0 \pm 0.05 \mathrm{~cm} \mathrm{~s}^{-1}$ (Fig. 3). Regression analysis found that drift speed (DS in $\mathrm{cm} \mathrm{s}^{-1}$ ) could be expressed as a function of wind speed (WS in $\mathrm{m} \mathrm{s}^{-1}$ ) by the following relationship (Fig. 3),

$\mathrm{DS}=3.9+2.3 \mathrm{WS}$ for $2 \leq \mathrm{WS} \leq 5 \mathrm{~m} \mathrm{~s}^{-1}\left(\mathrm{r}^{2}=0.99\right)$

Trials run with the addition of bile to the side of the tank resulted in no significant difference in the initial spreading rates at each wind speed. At all wind speeds, the rate of slick transport tended towards the constant rate of wind-induced surface drift. Slick transport rates reached the rates of surface drift within approximately $2.5,1$, and $0.5 \mathrm{~s}$ for wind speeds of 2,3 , and $5 \mathrm{~m} \mathrm{~s}^{-1}$, respectively.

\section{Bacterial distributions}

Bacteria introduced in slick material did not spread evenly with advancing slicks. Sampling over a centimetre scale, using the pipette, showed localised concentrations of Vibrio natriegens at the point source (Fig. 4). Sampling in the vicinity of the leading edge, using copier paper disks, showed localised concentrations of $V$. natriegens up to 10 times greater at the leading edge compared to just $5 \mathrm{~mm}$ behind the leading edge (Fig. 5). Control plate counts indicated that the inocula for the experiments in Fig. 5 were 4 times lower than the inocula for the experiments in Fig. 4. Multi-

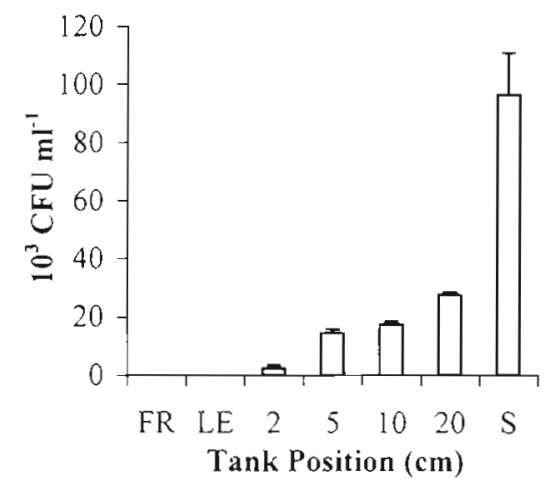

Fig. 4. Distribution of colony forming units (CFU) of Vibrio natriegens in spread bile slick. Samples were taken in front of the leading edge (FR), at the leading edge (LE), at the source of discharge (S), and 2,5,10, and $20 \mathrm{~cm}$ back from the leading edge. Error bars are $95 \%$ confidence intervals

plication by this factor indicates the maximum CFU for Fig. 5 was equivalent to $32 \times 10^{3} \mathrm{CFU}$ in Fig. 4 , exceeding all but the source concentration.

Bacteria already present in underlying waters (Red CFU) were not pushed back by the leading edge of the introduced slick, but were incorporated evenly along the slick (Fig. 5). There was no buildup of extant bacteria in front of the slick's leading edge as might be expected if displacement were occurring. The incorporation process was most pronounced across the first $17 \mathrm{~mm}$ of the slick and dropped by a factor of 2 to 3 thereafter. The uneven incorporation of extant bacteria within the slick suggests scale-dependent dynamics. However, for extant bacteria the main point is that incorporation, rather than displacement, is observed.

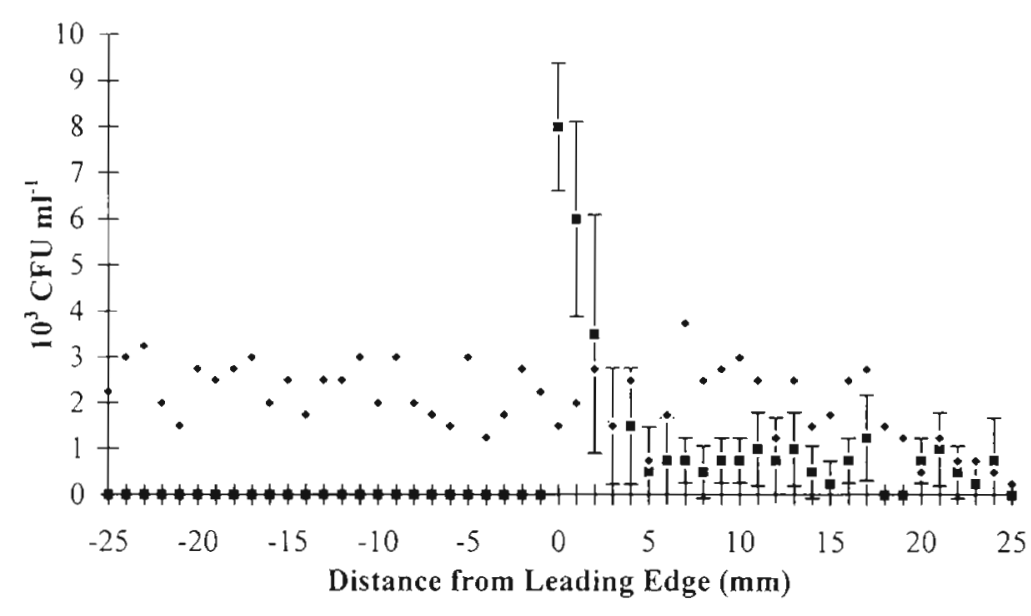

Fig. 5. Distributions of colony forming units (CFU) of Vibrio natriegens ( and red colony forming bacteria $(\bullet)$ near the leading edge of a spread bile slick. Error bars are $95 \%$ confidence intervals $\{\mathrm{Cl}$ \} for $V$. natriegens. The $95 \%$ $\mathrm{CI}$ for the red colony forming bacteria ( $\bullet$ ) are all approximately $20 \%$ of the mean values. Colonies in unslicked waters are to the left of zero and colonies within the slick are to the right 


\section{DISCUSSION}

Movement of water masses is generally controlled by wind-driven, subsurface currents. These currents are set up over long periods of time from prevailing wind patterns and extend deep into the water column. They transport large masses of water great distances relatively slowly (typically 1 to $2 \mathrm{~cm} \mathrm{~s}^{-1}$ ) (Bye 1988, Bearman 1993). However, wind-induced surface drift differs from this type of bulk water transport, as it is driven by small scale fluctuations in wind speed and direction and responds rapidly to any changes (Romano \& Marquet 1991).

The results presented here suggest that windinduced surface drift may be capable of transporting SSMs at faster rates than would occur through general circulation. Wind speeds of 2,3 , and $5 \mathrm{~m} \mathrm{~s}^{-1}$ are capable of generating surface drifts of 8,11 , and $15 \mathrm{~cm} \mathrm{~s}^{-1}$ respectively. At the wind speeds traled here, there is a distinct correlation between wind speed and surface drift (Eq. 1), however, due to the dynamics of the system, Eq. (1) can only be said to hold true for the range

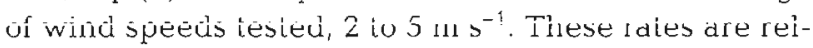
atively fast compared to bulk water transport rates of 1 to $2 \mathrm{~cm} \mathrm{~s}^{-1}$ (Bearman 1993). As an example, we have previously proposed (Hale \& Mitchell 1995) that distributions of coralline lethal orange disease (CLOD), observed by Little \& Littler (1995), resulted from winddriven surface transport of the SSM over a distance of more than $6000 \mathrm{~km}$. This mechanism would have transported CLOD parallel to the prevailing wind direction and across or against current patterns, explaining the rapid dispersal of CLOD observed in the South Pacific.

Laboratory studies using different tank dimensions and float types have produced a consistent relationship between wind speed and surface drift (Table 1). In this study, on average, the drift speed was $3.6 \pm 0.6 \%$ of the wind speed (Fig 3), which is in excellent agreement with $3.5 \pm 0.7 \%$ of the wind speed, found in previous studies (e.g Lange \& Hühnerfuss 1978). The tank used in this study was the smallest of those listed in Table 1. The consistency of the results presented here suggests our talcum powder method in a small tank represents a useful method of examining the dynamics of horizontal surface transport, without the need for a complex wind tunnel. The advantage of our method is that it is relatively small, portable, does not require floats and is easy to clean and manipulate

Rates of spreading in the laboratory were initially fast and then decreased to a constant rate. Initial spreading rates were $19.7 \pm 1.1( \pm \mathrm{SD})$ and $8.5 \pm 0.4 \mathrm{~cm}$ $\mathrm{s}^{-1}$ for bile and sewage spreading, respectively. The initially fast spreading rates decreased to constant rates of $8.4 \pm 1.2$ and $2.6 \pm 0.6 \mathrm{~cm} \mathrm{~s}^{-1}$, respectively
(Fig. 1). Vegetable and motor oils did not spread because they are hydrophobic and lack the strongly hydrophilic part that is characteristic of surfactants (Myers 1992)

The addition of talcum powder to the surface had a negligible effect on spreading rates. O'Brien et al. (1975) report that the use of talcum powder underestimated spreading rates of oleic acid by less than $10 \%$, compared to rates measured using thermistors. Measurement error in their study accounted for much of this difference.

While laboratory experiments were useful in examining the dynamics of the spreading process in the initial few seconds, measurements made in the field were important to examine surfactant spreading on a larger scale, with no edge effects. Bile spread over the first $1 \mathrm{~m}$ at $16 \mathrm{~cm} \mathrm{~s}^{-1}$. The absence of any edge effects explains why this faster rate is retained longer at sea than in tanks. Experiments conducted in the field indicate that a bile slick will continue spreading until all available material has spread into a monomolecular layer. The distance over which a slick may spread depends on ine volume of suríactani availabie and ine inickness of the slick. Field experiments found that following an initially fast rate of spreading, the rate decreased exponentially towards a constant rate of $5.3 \mathrm{~cm} \mathrm{~s}^{-1}$. This converts to a rate of $4.6 \mathrm{~km} \mathrm{~d}^{-1}$, which may be further enhanced by any wind-induced surface drift.

The bile slick spread in the field remained coherent on the surface of the water on both days, despite the presence of waves on the second day. The presence of waves had no significant effect on slick spreading rates, nor on the direction of slick transport during active spreading. Therefore, slicks are capable of spreading independent of water currents and waves. These results are supported by Langmuir (1938) and Weller et al. (1985) who observed that natural slicks will change their orientation in response to changes in wind direction, while the direction of waves remains unchanged

The persistence of visible slicks on the surface depends on the amount of mixing with underlying waters. The nature of the mixing processes at the surface differs depending on whether wind speed is above or below a critical level (Webster \& Hutchinson 1994). This is because below a critical wind speed, the wind-generated turbulence is incapable of mixing below the surface. Above the critical wind speed, interactions between wind-generated turbulence, mean currents and waves cause active turbulent mixing to subsurface waters (Hutchinson \& Webster 1994). Data not presented here show that slicks remain coherent on the surface at wind speeds of 2 to $3 \mathrm{~m} \mathrm{~s}^{-1}$, however, at $5 \mathrm{~m} \mathrm{~s}^{-1}$, above the critical wind speed, slicks began to break up and became patchy. 
Webster \& Hutchinson (1994) report that buoyant phytoplankton in surface waters were found to concentrate toward the downwind end of a lake for wind speeds less than $3 \mathrm{~m} \mathrm{~s}^{-1}$, but that turbulent mixing caused by winds at greater speeds results in the continual ejection of floating cells or colonies downward. Le Fèvre \& Bourget (1991) suggest that the surface microlayer may provide a neustonic niche for cirripede larvae to allow dispersal over large distances, in a relatively short time. Therefore, whether or not the wind speed is above or below the critical wind speed will have a profound effect on the horizontal distribution of slick material and any associated organisms, as well as on their vertical distribution. Furthermore, with persistent winds, streaks across the surface caused by Langmuir circulation may lead to a heterogenous spatial distribution of organisms, with high concentrations of organisms within the streaks and low concentrations between them.

The rates of surface drift measured for wind speeds of 2,3 , and $5 \mathrm{~m} \mathrm{~s}^{-1}$ are equivalent to transport rates of 7, 9.5 , and $13 \mathrm{~km} \mathrm{~d}^{-1}$. These transport rates are for wind-induced surface drift without surfactant spreading. SSM transport rates may be further enhanced by active surfactant spreading, where the spreading rate is faster than the surface drift and wind speed is below the critical level, above which mixing occurs.

Results of this study indicate that bacteria introduced to the microlayer in surfactant material are capable of being transported in spreading slicks. A gross sampling method (centimetre scale) showed the major proportion of bacteria lagging some distance behind the leading edge, close to the point source (Fig. 4). However, a higher resolution sampling method using sterile copier paper disks found localised concentrations of bacteria at the leading edge of slicks (Fig. 5). As the majority of bacteria were observed lagging behind the leading edge, this seems surprising. The Reynolds ridge reported by Harper (1992) may provide a mechanism by which bacteria may be concentrated at the leading edge of a spreading slick. The ridge is seen as a slight rise in the surface level at the leading edge of a slick actively spreading along surface tension gradients. This phenomenon occurs at the transition from an apparently free surface to an almost stationary surface, caused by a gradient of surface tension. Such a mechanism may explain the small scale concentration of bacteria close to the leading edge. If the 'Reynolds ridge' is capable of holding bacteria at the leading edge, then long distance transport of bacteria from a point source, with little dilution at the leading edge, may be feasible. In areas of high productivity, such as the SSM (Kjelleberg et al. 1979, Plusquellec et al. 1991), only a small number of introduced bacteria would be required to inoculate a natural community.
Bacteria already present at the surface in inoculated bulk water were not pushed back by the advancing slick, but were incorporated and spread evenly across the slick. Therefore, introduced bacteria may alter the species composition of marine bacterioneuston communities by becoming incorporated into them, rather than replacing extant bacterioneuston communities.

Horizontal surface transport processes may have a large influence on the fate of bacteria introduced to surface waters from terrestrial sources. Distributions of bacteria, both horizontally and vertically, may be dependent on rates of surfactant material spreading, wind-induced surface drift and mixing, rather than solely on bulk water circulation patterns. The combination of wind-driven surface transport and active spreading of slick material along surface tension gradients provides a unique mechanism by which bacterioneuston (and the chemical and biological components associated with them) are transported over large distances, independent of the speed and direction of bulk water transport. Such a transport mechanism should be considered in the study of neuston community dynamics and when attempting to predict the fate of microorganisms released from terrestrial sources.

\section{LITERATURE CITED}

Adamson AW (1990) Physical chemistry of surfaces, 5th edn. Wiley-Interscience Publication, New York

Al-Rabeh A.H, Cekirge HM, Gunay N (1992) Modelling the fate and transport of Al-Ahmadi oil spill. Water Air Soil Poll 65:257-279

Al-Rabeh AH, Gunay N (1992) On the application of a particle dispersal model. Coast Eng 17:195-210

Aveyard R, Binks BP, Fletcher PDI, Peck T, Garret PR (1993) Entry and spreading of alkane drops at the air/surfactant solution interface in relation to foam and soap film stability. J Chem Soc Faraday Trans 89:4313-4321

Bearman G (ed) (1993) Ocean circulation. Peragon Press, Oxford

Bye JAT (1988) Physical oceanography of Gulf St Vincent and Investigator Strait. In: Twidale CR, Tyler MJ, Webb BP (eds) Natural history of the Adelaide region. Royal Society of South Australia, Adelaide, p 143-160

Carlson DJ (1982) Surface microlayer phenolic enrichments indicate sea surface slicks. Nature 296:426-429

Davies JT, Rideal EK (1963) Interfacial phenomena, 2nd edn. Academic Press, New York

Deo AV, Kulkarni SB, Gharpurey MK, Biswas AB (1964) On the rate of spreading of long chain n-alcohols and n-alkoxy ethanols from solid into monolayer on water. J Colloid Sci 19:820-830

Dobroklonskiy SV, Lesnikov BM (1972) A laboratory study of the surface layers in drift currents. Izv Atmos Oceanic Phys 8:686-692

Duce RA, Quinn JG, Olney CE, Piotrowicz SR, Ray BJ, Wade TL (1972) Enrichment of heavy metals and organic compounds in the surface microlayer of Narrangansett Bay, Rhode Island. Science 176:161-163

Ewing $G(1950)$ Slicks, surface films and internal waves. J Mar Res 9:161-187 
Hale MS, Mitchell JG (1995) CLOD spreading in the sea surface microlayer. Science 270:897-898

Hardy JT, Apts CW, Crecelius EA, Bloom NS (1985) Sea surface microlayer enrichments in an urban and rural bay. Estuar Coast Shelf Sci 20:299-312

Harper JF (1992) The leading edge of an oil slick, soap foam or bubble stagnant cap in stokes flow. J Fluid Mech 237: $23-32$

Haslewood GAD (1967) Bile salts. Methuen \& Co Ltd, London

Hutchinson PA, Webster PA (1994) On the distribution of blue-green algae in lakes: wind-tunnel tank experiments. Limnol Oceanogr 39:374-382

Katti SS, Sansare SD (1970) Pressure-area isotherms, rates of spreading and equilibrium spreading pressures of $\mathrm{n}$ alkoxy propanols and oxy butanols at $25^{\circ} \mathrm{C}$. J Colloid Interf Sci 32:361-366

Keulegan GH (1951) Wind tides in small closed channels. $J$ Res Nat Bur Stand 46:358-381

Kjelleberg S, Stenström ST, Odham G (1979) Comparative study of different hydrophobic devices for sampling lipid surface films and adherent microorganisms. Mar Biol 53: $21-25$

Lange P, Hühnerfuss H (1978) Drift response of monomolecular slicks to wave and wind action. J Phys Oceanogr 8: $142-150$

Langmuir I (1938) Surface motion of water induced by wind Science 87:119-123

Le Fèvre J, Bourget E (1991) Neustonic nıche tor cirripede larvae as a possible adaptation to long-range dispersal. Mar Ecol Prog Ser 74:185-194

Littler MM, Littler DS (1995) Impact of CLOD pathogen on Pacific coral reefs. Science 267:1356-1359

Maki JS (1993) The air-water interface as an extreme environment. In: Edgcumbeford T (ed) Aquatic microbiology: an ecological approach. Blackwell Scientific Publications, London, p 409-439

Mitchell JG, Pearson L, Bonazinga A, Dillon S, Khouri H, Paxinos $R$ (1995) Long lag times and high velocities in the motility of natural assemblages of marine bacteria. Appl Environ Microbiol 61:877-882

This article was submitted to the editor
Mizuno S, Mitsuyasu H (1973) Effects of advective wind on the phase velocity of mechanically generated water waves. Rep Res Inst Appl Mech 21:33-52

Myers D (1992) Surfactant science and technology, 2nd edn. VCH Publishers, New York

O'Brien JA (1971) Wind tunnel experiments on oil slick transport. J Hydraul Res IAHR9:197-215

O'Brien RN, Feher Al, Leja J (1975) Interferometric flow profiles produced in water by a spreading monolayer. $\mathrm{J} \mathrm{Col}$ loid Interf Sci 51:366-372

O'Brien RN, Feher AI, Leja J (1976) Spreading of monolayers at the air-water interface 1 . A new method of measuring spreading rates (speed). J Colloid Interf Sci 56:469-473.

Plate EJ, Chang PC. Hindy GM (1969) Experiments on the generation of small water waves by wind. J Fluid Mech 35: $625-656$

Plusquellec A, Beucher M. LeLay C, LeGal Y, Cleret JJ (1991) Quantitative and qualitative bacteriology of the marine water surface microlayer in a sewage polluted area. Mar Environ Res 31:227-239

Romano J, Marquet R (1991) Occurrence frequencies of seasurface slicks at long and short time-scales in relation to wind speed. Estuar Coast Sheif Sci 33:445-458

Schmidt-Nielson K (1990) Animal physiology: adaptation and environment, 4th edn. Cambridge University Press, Cambridge

Shemdin $O H$ (1972) Wind-generated current and phase speed of wind waves. J Phys Oceanugh 2:411-419

Webster IT, Hutchinson PA (1994) Effect of wind on the distribution of phytoplankton cells in lakes revisited. Limnol Oceanogr 39:365-373

Weller RA, Dean JP, Marra J, Price JF, Francis A, Boardman DC (1985) Three-dimensional flow in the upper ocean. Science 227:1552-1556

Weller RA, Price JF (1988) Langmuir circulation within the oceanic mixed layer. Deep Sea Res 35:711-747

Wright JW, Keller WC (1971) Doppler spectra in microwave scattering from wind waves. Phys Fluids 14:466-474

Wu J (1968) Laboratory studies of wind-wave interactions. J Fluid Mech 34:91-112

Manuscript first received: July 25, 1996

Revised version accepted: December 4, 1996 